\title{
MENAKAR PERAN PESANTREN \\ DALAM MENGEMBANGKAN PENDIDIKAN TINGGI MENGHADAPI ERA GLOBALISASI
}

\author{
S. Ali Jadid al Idrus \\ IAIN Mataram, Mataram, Indonesia \\ s_alijadid75@gmail.com
}

\begin{abstract}
Abstrak
Pesantren diharapkan menjadi lembaga yang mampu mengantarkan peserta didiknya sebagai subyek atau pelaku utama pada era global. Mampu bergerak terpadu memadukan sains, teknologi, seni, nilai, dan lingkungan dalam proses pembangunan individu-individu masyarakat. Pesantren diharapakan untuk bertransformasi menjadi lembaga yang tidak hanya fokus pada pengajaran ilmu-ilmu keagamaan namun juga mengajarkan ilmu-ilmu sains, teknologi, dan informatika yang tetap mempertahankan nilai keislaman baik dalam proses maupun muatan ilmunya sehingga nantinya mampu melahirkan para kyai sekaligus saintis. Oleh karena itu, pengembangan pendidikan tinggi di pesantren diharuskan untuk mengedepankan kajian keilmuan yang terintegrasi guna mewujudkan pribadi-pribadi unggul dan berdaya saing.

Kata Kunci: Pesantren; Islamic Borading Schools; Globalisasi; Pendidikan Tinggi; Integrasi Keilmuan;

Abstract

Pesantren (Islamic Boarding Schools) are expected to be institutions that could lead their students to be main actors of current global era. Their students are nowadays expected to be able to integrated sciences, technology, art, life value and environment in developing society. Pesantren are also looked forward to transform themselves into institutions that not only focus on teaching religious materials but also focus on sciences, technology and informatics retaining Islamic values both in its process and its contents so that their outcomes are not only to be Islamic scholars but also scientists. Therefore, the development of higher education in Pesantren should promote integrated studies in order to build superior individuals having a strong competitiveness. Keywords: Pesantren; Islamic Borading Schools; Globalization; Higher Education; Knowledge Integration;
\end{abstract}

\section{PENDAHULUAN}

Islam adalah agama perdamaian, agama universal dan rahmat bagi seluruh alam yang menawarkan hidup berkualitas antar sesama manusia dalam bentuk belas asih, kemurahan, toleransi, dan cinta yang sejatinya mampu menjadi kekuatan global. Islam dengan paradigma rahmatan lil alamin sebagai elemen dasar yang ditanamkan kedalam jiwa para santrinya 
al Idrus, S. (2016). MENAKAR PERAN PESANTREN DALAM MENGEMBANGKAN PENDIDIKAN TINGGI MENGHADAPI ERA GLOBALISASI. JURNAL TATSQIF, 14(2). Retrieved from http://ejurnal.iainmataram.ac.id/index.php/tatsqif/article/view/1082

dapat mengatasi benturan-benturan peradaban atau implikasi negatif dari perkembangan dunia (Baba, 2006).

Pada era globalisasi dan modernisasi, keberadaan pondok pesantren memiliki spesifikasi peran tidak saja sebagai lembaga dakwah, lembaga pendidikan, maupun lembaga social, lebih dari itu semua pesantren adalah bagian integral dari masyarakat secara keseluruhan yang tidak mungkin menutup mata dan menjauh dari realitas yang ada. Bentuk falsafah yang sederhana namun mampu mentransformasikan potensi dan menjadikan diri pesantren sebagai agent of change bagi masyarakat sehingga eksistensinya identik dengan lembaga pengembangan masyarakat. Sampai sekarang masih terdapat persantren yang berdiri di atas ideologi fiqih-sufistik sebagai paradigma pendidikannya, sehingga kurang menerima perkembangan ilmu pengetahuan serta saham bagi pemecahan permasalahan kemasyarakatan secara luas.

Sistem dan nilai-nilai Peseantren dengan keterpaduan syariat Islam, sains, teknologi, dan seni dapat diaktualisasikan dengan upaya serius di lingkungan pendidikan tinggi. Pesantren dan masyarakat merupakan bagian dari sistem social yang tidak bisa dipisahkan. Masyarakat atau institusi sosial yang memiliki ciri-ciri kemandirian, toleransi, keswadayaan, kerelaan, dan menjunjung tinggi norma serta serta etika yang berlaku di tengah masyarakat yang biasa disebut masyarakat madani (civil society) (Muqodim, 2006). Langkah menuju masyarakat madani sebagaimana yang dicita-citakan dalam ruh ajaran islam tersebut tidak mungkin dicapai tanpa mengoptimalkan kwalitas sumber daya manusia yang hanya akan terlaksana jika segala lini bergerak secara terpadu dimana manusia menjadi subyek utamanya.

Sistem yang ditampilkan pondok pesantren secara kualitatif maupun kuntitatif memiliki keunikan secara khusus dengan pendidikan umum dengan memperhatikan beberapa aspek yaitu, (1) memakai sistem tradisional yang memiliki kebebasan penuh dibandingkan dengan sekolah 
al Idrus, S. (2016). MENAKAR PERAN PESANTREN DALAM MENGEMBANGKAN PENDIDIKAN TINGGI MENGHADAPI ERA GLOBALISASI. JURNAL TATSQIF, 14(2). Retrieved from http://ejurnal.iainmataram.ac.id/index.php/tatsqif/article/view/1082

lainnya, (2) kehidupan yang demokratis. (3) tidak mengidap penyakit simbolis yaitu memperoleh gelar dan ijazah, (4) sistem pondok pesantren mengutamakan kesederhanaan, idealisme, persaudaraan, persamaan, rasa percaya diri, dan keberanian hidup, (5) alumni pondok pesantren tidak ingin menduduki jabatan pemerintahan sehingga tidak dapat dikuasai oleh pemerintah (Arif, 2008).

Paradigma pendidikan pesantren hendaknya lebih kuat pada pemahaman secara filosofis, psikologis maupun aspek metodologi serta diharuskan mengadakan usaha kontekstualisasi konstruktif sistem dan orientasi kependidikannya seperti aspek-aspek administrasi, diferensiasi struktural, ekspansi kapasitas, dan transformasi out put pesantren (Mastuhu, 1994). Pesantren berkembang menjadi lembaga pendidikan secara reguler dan diikuti oleh masyarakat, dalam pengertian memberi pelajaran secara material dan immaterial. Pendidikan secara material itu adalah diharap setiap santri mampu menghatamkan kitab-kitab kuning sesuai dengan target yang diharapkan. Sedangkan pengajaran dalam pengertian immaterial cenderung berbentuk sesuatu upaya perubahan sikap santri, agar santri manjadi seorang yang tangguh dalam manghadapi kehidupannya sehari-hari.

Memasuki melinium ketiga yang ditandai sebagai abad informasi dimana ilmu pengetahuan berkembang dan tersebar dengan sangat cepat maka pesantren harus melakukan penetrasi dalam menghadap segala tantangan (Tilaar, 2000). Konstruksi pemikiran sangat penting dilakuka pesantren, terutama dalam menghadapi tantangan nyar era global yang sudah menembuh ruang dan waktu dengan indikasi kyai merupakan kelompok profesi terpelajar (learned proffesion) kemampuan mengakses kelimuan secara padu dan kaffah, mampu mengisi sisi strategis pesantren dengan segenap tingkatan umur, sosial, ekobomi, budaya, dan intelektual. Penerapan kurikulum pendidikan yang mencerminkan keseimbangan profesional dan proporsional dalam kebutuhan santri antara dunia dan 
al Idrus, S. (2016). MENAKAR PERAN PESANTREN DALAM MENGEMBANGKAN PENDIDIKAN TINGGI MENGHADAPI ERA GLOBALISASI. JURNAL TATSQIF, 14(2). Retrieved from http://ejurnal.iainmataram.ac.id/index.php/tatsqif/article/view/1082

akhirat, akal dan kalbu, jasmani dan rohani, serta potensi diri dan potensi lingkungannya.

Penetrasi yang dilakukan pesantren era teknologi industri yang menggelobal berorientasikan pada: Pertama, upaya mewariskan paham/pola keagamaan denga ditekankan kepada proses memperoleh kemampuan metodologis dalam memahami kesan dan pesan yang diberikan agama. Kedua, tidak terpaku pada romantisme berlebihan namun diarahkan kepada pembentukan berpikir obyektif dalam menyikapi tantangan kehidupan. Ketiga, materi pengajaran agama hendaknya diintegrasikan dengan penumbuh kembangan sikap kepedulian sosial. Keempat, dikembangkan wawasan emansipatoris sehingga menumbuhkan kemampuan metodologis santri dalam mempelajari substansi atau materi agama. Kelima, pendidikan keagamaan diarahkan untuk menanamkan keharuan emosional keagamaan (akhlakul karimah) (Abdurrahman, 1985).

Pada kondisi ini pendidikan tinggi yang dikembangkan pesantren akan hidup dan berkembang, jika kyai dan santri mampu mengadaptasi kepekaan intelektual, moral dan spiritual, maka akan lahirlah pesanten masa depan sebagai lembaga pendidkan masa depan yang tafakkuh fi ad din dengan kekuatan Islamic values memiliki kemampuan melakukan social control dan social engeneering serta community development.

Berdasarkan uraian di atas, kajian ini bertujuan untuk mengetahui sejauh mana peranan lembaga pendidikan pesantren dalam mengembangkan pendidikan tinggi menghadapi era globalisasi.

\section{METODE}

Kajian ini merupakan kajian pustaka/literatur. Sejumlah literatur yang relevan dikaji untuk mendapatkan kesimpulan mengenai sejauh mana peranan pesantren dalam mengembangkan pendidikan tinggi menghadapi era globalisasi. 
Selain itu, refleksi tentang perkembangan pesantren saat ini juga menjadi pertimbangan dalam tulisan ini dalam memberikan penilaian terhadap potensi dan peranan pesantren dalam mengembangkan pendidikan tinggi menghadapi era globalisasi.

\section{PEMBAHASAN}

\section{Globalisasi sebagai Tantangan Global Pendidikan Tinggi di Pesantren}

Dunia yang terbuka memberikan peluang-peluang baru, tetapi juga tantangan baru. Dunia yang terbuka bukannya tanpa proteksi, setiap bangsa menginginkan bangsanya akan maju setara dengan bangsa-bangsa lain yang maju. Sejalan dengan maraknya perdagangan dunia, maka konsumerisme akan berkembang pesat. Dunia dalam era globalisasi adalah dunia yang mengejar kualitas dan keunggulan. Dengan perjuangan tersebut diharapkan mesyarakat menjadi dinamis, terus menerus maju dan mengejar yang terbaik (Abdurrahman, 1985). Globalisasi sebagai suatu konsep yang sudah masuk dalam pikiran sebagian warga masyarakat, globalisasi merupakan fenomena yang mengandung perubahan yang bersifat majemuk dan drastis dalam seluruh aspek kehidupan masyarakat, khususnya aspek ekonomi, politik dan cultural bahkan pendidikan.

Era globalisasi disebut sebagai era kesejagatan menimbulkan perubahan penting dalam berbagai aspek kehidupan; ekonomi, politik, sosial, budaya, teknologi, pendidikan dan lain-lain. Berbagai kemajuan penting dalam teknologi informasi, komunikasi, dan transportasi telah mempercepat jika tidak menyebabkan proses globalisasi tersebut. Hasilnya, informasi instan dapat diterima dan siikuti masyarakat di berbagai penjuru dunia, dan tidak trelalu lama, perubahan pada tingkat global memengaruhi masyarakat-masyarakat. 
Era globalisasi bukannya tanpa konsekuensi, oleh sebab itu perlu dicermati dampak positif maupun negatifnya. Diantara dampak dari globalisasi ialah munculnya suatu masyarakat mega-kompetisi dimana setiap orang berlomba-lomba untuk membuat yang terbaik, mencapai yang terbaik. Globalisasi sebuah era maju yang tanpa kelemahan dan kekurangan. Saul dalam bukunya The Coolapse Of Globalism mengatakan bahwa seolah-olah tanpa asal-usul, globalisasi muncul pada tahun 1970an, tumbuh besar dan dewasa, diselimuti dengan aura inklusivitas. Para penganjur dan penganutnya dengan mantap mengatakan, melalui prima madzhab khusus ilmu ekonomi, bahwa rakyat diseluruh dunia akan menempuh arah baru, yang saling terkait erat dan positif. Misi ini diubah menjadi kebijakan dasn hukum selama 20 tahun - 1980-an dan 90-an dengan ditopang oleh kekuatan keniscayaan (Ishomuddin, 2011).

Era global dan globalisasi tidak terelakkan lagi, juga menimbulkan perubahan penting dalam berbagai aspek dunia pendidikan secara kelembagaan, globalisasi mendorong terjadinya proses otonomisasi, devolusi, desentralisasi, dan privatisasi pendidikan. Pada tingkat pendidikan dasar dan menegah, orang bias menyaksikan gejala desentralisasi, di mana pemerintah local bersama masyarakat tempatan semakin memainkan peranan lebih besar dalam merancang dan menyelenggarakan pendidikan. Pada tingkat pendidikan tinggi, terjadi peningkatan proses otonomisasi dan privatisasi, di mana peranan pemerintah semakin mengecil, dan sebaliknya peranan stake holders kian membesar.

Kemudian, dalam hal substansi pendidikan, globalisasi juga menimbulkan perubahan penting selaras dengan perkembangan masyarakat globalisasi yang pada dasrnya bertumpu pada 'knowledgebased society' - jika tidak pada 'knowledge-based economy' - subyek (mata pelajaran atau mata kuliah) juga mengalami perubahan. Terdapat kecenderungan kuat terjadinya penyederhanaan muatan kurikulum. 
Subyek yang dipandang tidak terlalu penting dan tidask relevan dengan kebutuhan global dihilangkan dari kurikulum. Sebaliknya, subyek yang urgen dan instrumental bagi peserta didik dalam menghadapi realitas globalisasi, semakin mendapat penekanan penting, atau bahkan diprioritaskan.

Terakhir, globalisasi yang sekali lagi ditandai kemajuan penting dalam teknologi informasi dan komunikasi mendorong terjadinya pula dalam pembelajaran. Dalam perspektif makro, kemajuan teknologi informasi dan komunikasi mempercepat proses demokratisasi dan equity dalam pembelajaran. Guru atau tenaga pengajar kini tidak lagi merupakan satu-satunya narasumber dalam proses pembelajaran. Teknologi informasi dan komunikasi yang kini ada (existing) - dan juga akan terus berkembang - semakin memuingkinkan peserta didik untuk mengakses sendiri beragam sumber belajar. Karena itu, jika guru atau tenaga pengajar tetap ingin memainkan peran senteral dalam proses pembelajaran, mereka harus melakukan perubahan atau sedikitnya penyesuaian dalam paradigm, strategi, pendekatan, dan teknologi pembelajaran. Jika tidak, tenaga pengajar akan kehilangan makna kehadirannya dalam proses pembelajaran.

Dari fenomena-fenomena tersebut, Ishomuddin menjelaskan akibat era globalisasi, maka perguruan tinggi yang dikembangkan pondok pesantren dihadapkan dengan beberapa tantangan sebagai berikut:

a. Dunia tanpa batas (borderless world) wajah abad ke 21 adalah abad kemajuan teknologoi khususnya teknologi komunikasi yang melahirkan suatu bentuk dunia tanpa batas (border world).

b. Krisis moral dan etika (the crisis of moral and ethics). Terlalu banyak peristiwa yang dapat kita identifikasi sebagai krisis moralitas dan etika yang melanda sebuah bangsa. didasari oleh perilaku-perilaku yang terpuji dan baik dalam pandangan islam.

c. Pudarnya identitas bangsa (the weakness of nation identity). 
d. Sebagai pendidikan tinggi yang memiliki cirri khas keislaman, perguruan tinggi agama islam harus mampu menanamkan komitmen keislaman dan kebangsaan melalui proses-proses pengajarannya kepada para mahasiswa.

e. Mega-kompetisi (mega-competition). Gelombang globalisasi melahirkan dunia yang terbuka telah mengubah semua aspek kehidupan manusia baik di dalam kehidupan perdagangan, politik, social, budaya serta hak-hak dan kewajiban manusia..

f. Masyarakat ilmu pengetahuan (knowledge society). Masyarakat abad 21 sebagai masyarakat ilmu pengetahuan (knowledge society) menuntut setiap individu menguasai atau setidaknya mempunyai pengertian tentang pengaruh ilmu pengetahuan di dalam kehidupan (Ishomuddin, 2011).

Berdasarkan fenomena tersebut, maka misi pendidikan pondok pesantren terus mengalami perubahan sesuai dengan arus kemajuan zaman yang ditandai dengan munculnya IPTEK. Perubahan sistem pendidikan menjadikan fungsi pondok pesantren sebagai lembaga pendidikan yang multi fungsi, di samping pola pendidikan secara tradisional diterapkan, namun harus juga pola menerapkan pendidikan modern (Depag RI, 2003). Seluruh kekuatan ini melahirkan apa yang disebut dengan kesadaran global (global consciousness). Kesadaran global bukan berarti melumatkan manusia itu menjadi partikel-partikel yang tidak berarti, tetapi justru menuntut sumbangan dari setriap individu dalam membina suatu masyarakat baru yaitu masyarakat yang lebih baik. Masyarakat yang lebih baik itu adalah hasil dari prestasi dan kreatifitas manusia yang muncul karena kompetisi. Pendidikan tinggi islam berdiri sejajar dengan pendidikan-pendidikan tinggi umum lainnya dituntut mampu menghadapi persaingan global baik dalam bidang akademik maupun non akademik 
Pemahaman fungsi pondok pesantren sebagai lembaga pendidikan terletak pada kesiapan pesantren dalam menyiapkan diri untuk ikut serta dalam pengembangan dalam pembangunan dibidang pendidikan dengan sejalan adanya perubahan sistem pendidikan sesuai dengan arus perkembangan zaman dan teknologi secara global. Sistem pendidikan pondok pesantren terus menyesuaikan diri dengan lingkungan pendidikan dengan prinsif masih tetap dalam kawasan prinsif agama. Oleh karena itu, pesantren benar-benar sebagai partner yang intensif dalam pengembangan pendidikan yang dibuktikan dengan makin meluasnya pendidikan pesantren ke seantero dunia (Ghazali, 2001). Perguruan tinggi agama islam memegang teguh dan berbasis pada islam dituntut untuk melahirkan sarjana yang menguasai bidang ilmunya dan mengamalkan ilmunya sehingga setelah menjadi sarjana mereka tetap berada dalam koridor sebagai sarjana yang menjunjung tinggi nilai-nilai keislaman dan tetap mencintai dan mengabdi kepada bangsanya

\section{Peran Kiyai dalam Pengembangan Pendidikan Tinggi di Pesantren}

Pengembangkan pendidikan tinggi di pesantren menunjukkan tingkat kompleksitas persoalan yang beragam bahwa merupakan sistem yang terdiri dari beberapa komponen saling berkaitan dan saling mempengaruhi antara komponen satu dengan lainnya. Komponenkomponen dalam pengembangkan pendidikan tinggi di pesantren yaitu: Pertama, perencanaan strategik yang terdiri dari Visi, Misi, Tujuan Strategik dan Strategik Utama (Induk) organisasi. Kedua, Perancanaan Operasional yang terdiri dari Sasaran dan Tujuan Operasional, Pelaksanaan Fungsi-fungsi Manajemen berupa fungsi Pengorganisasian, Fungsi Pelaksanaan dan Fungsi Penganggaran, Kebijaksanaan Situsional, Jaringan Kerja Internal dan Eksternal, Fungsi Kontrol dan Evaluasi serta Umpan Balik (Ghazali, 2001). Perguruan tinggi harus berupaya mengembangakan visi, tujuan, dan sasaran yang telah dibuat kedalam upaya-upaya untuk mencapai visi, tujuan, dan sasran tersebut. Peroses 
pencapaian visi perguruan tinggi akan dapat dilaksanakan dengan baik jika perguruan tinggi memiliki strategi utama dalam proses pengembangannya.

Pengembangan pendidikan tinggi di pesantren tidak dapat dipisahkan dari peran para kiyai dan pengelola pesantren secara komprehensip. Sebagai lembaga pendidikan, pengembangan pendidikan tinggi di pesantren harus mengembangkan kegiatan akademik dalam upaya untuk menghasilkan lulusan sebagaimana yang dicitakannaya. Menghasilkan lulusan harus berkaitan dengan; kebutuhan dan harapan stakeholder serta regulasi yang berlaku (Muhaimin dkk, 2009). Kebutuhan dan harapan stakeholder diketahui dari berbagai proses pengukuran tentang stakeholder. Sedangkan berkaitan dengan regulasi, strategi yang dikembangkan perguruan tinggi harus berpijak pada berbagai regulasi yang ada.

Menurut E.A. Kuncoro yang menyampaikan pendapat Kerr dalam Alma (Muhaimin dkk, 2009) bahwa untuk menggerakkan roda organisasi perguruan tinggi maka diperlukan pemimpin yang betul-betul berkualitas baik. Pemimpin perguruan tinggi dalam hal ini adalah Rektor mempunyai tanggung jawab yang istimewa karena harus berperan sebagai leader, educator, creator, initiator, cocensus seeker dan persuader. Dalam pemimpin organisasi seorang pemimpin perguruan tinggi harus mampu menggerakkan kekuatan organisasi yang dimilikinya untuk bersaing dalam industry yang sama. Kekuatan organisasi ini harus menjadi kekuatan daya saing (competitiveness strengths) dalam memenangkan persaingan. Penjelasan lain disampaikan Sallis (Sallis, 2010:87) bahwa di sebuah perguruan tinggi, faktor kepemimpinan merupakan salah satu kunci utama untuk mencapai keberhasilan, disamping program, ketersediaan sumber daya, budaya akademik, dan faktor lainnya. 
Para penentu kebijakan yang ada di pesantren harus memiliki strategi utama, kebijakan-kebijakan strategis untuk diambil serta digunakan sebagai patoakan dalam pengembanga program yang lebih detil. Strategi utama merupakan sejenis panduan global dalam pembuatan dan pelaksanaan program kegiatan. Proses atau rangkaian kegiatan pengambilan keputusan yang bersifat mendasar dan menyeluruh, disertai penetapan cara melaksanakannya, yang dibuat oleh manajemen puncak dan diimplementasikan oleh seluruh jajaran di dalam suatu organisasi, untuk mencapai tujuannya (Nawawi, 2005:48). Strategi utama pondok pesantren dalam mengembangkan pendidikan tinggi antara lain perencanaan bersekala besar (perencanaan strategik) yang berorientasi pada jangkauan masa depan yang jauh (visi), dan ditetapkan sebagai keputusan manajemen puncak (keputusan yang bersifat mendasar dan prinsipil), agar memungkinkan organisasi berinteraksi secara efektif (disebut misi), dalam usaha menghasilkasn sesuatu (perencanaan operasional) organisasi.

Problema manajemen perguruan tinggi, telah menjadi isu utama rehabilitasi dan rekonstruksi dunia pendidikan tinggi. Penerapan manajemen perguruan tinggi selama ini, belum banyak membawa dampak signifikan bagi perwujudan tri dharma perguruan tinggi yang bermutu. Pendidikan tinggi tidak dapat berkembang dengan baik, bila hanya memfokuskan diri pada pengajaran semata dan tidak memberikan perhatian pada riset dan pengabdian masyarakat. Pendidikan pesantren tidak lagi dianggap sebagai manajemen sosial yang dikendalikan oleh subyek berwawasan sempit (pendekatan kekeluargaan), namun dikembangkan dalam pengelolaan pendidikan islam dalam pola manajemen strategik keputusan dan tindakan yang menghasilkan formulasi dan impelementasi rencana-rencana mencapai perubahan ke arah masa kemajuan, bukan lagi penerapan manajemen insruksional yang kaku serta mengakumulasikan kerawanan masalah. 
al Idrus, S. (2016). MENAKAR PERAN PESANTREN DALAM MENGEMBANGKAN PENDIDIKAN TINGGI MENGHADAPI ERA GLOBALISASI. JURNAL TATSQIF, 14(2). Retrieved from http://ejurnal.iainmataram.ac.id/index.php/tatsqif/article/view/1082

\section{Pendidikan Tinggi pada Pesantren; Pusat Pengembangan Peradaban Islam}

Pendidikan Islam tidak lepas dari peran pesantren sebagai salah satu institusi pendidikan Islam yang menjadi wahana resistensi moral dan budaya atau pewaris tradisi intelektual Islam tradisional,demiklian pula yang diharapkan pada pendidikan tingginya. Menilik keberadaan pesantren masih sedemikian penting dalam pemberdayaan masyarakat. Pendidikan Islam sebagai wahana pembebasan bagi umat manusia, sebagaimana tertuang dalam teks-teks Al-Qur'an dan diperkuat oleh AlHadist, namun sesungguhnya secara kontekstual hal tersebut sudah tersirat pada ayat-ayat Tuhan yang tidak tertulis, sehingga sangat memungkinkan bagi manusia untuk menginterpretasikan Al-Qur'an secara skriptual dan menginterpretasikan ayat-ayat Allah secara konstektual

Pendekatan yang dapat digunakan dalam usaha menampilkan citra Islam ke dalam kehidupan kemasyarakatan adalah pendekatan sosiokultural. Pendekatan ini mengutamakan sikap mengembangkan pandangan dan perangkat kultural yang dilengkapi oleh upaya membangun sistem kemasyarakatan yang sesuai dengan wawasan budaya yang ingin dicapai. Pendekatan ini lebih mementingkan aktifitas budaya dalam konteks pengembangan lembaga-lembaga yang dapat mendorong transformasi sistem sosial secara evolutif dan gradual. Pendekatan seperti ini dapat mempermudah masuknya agenda Islam ke dalam agenda nasional bangsa secara inklusifistik.

Bukan berarti penguasaan terhadap ilmu pengetahuan membebaskan manusia dari nilai-nilai agama. Tetapi kedua nilai tersebut - ilmu pengetahuan dan agama - saling mengisi, saling mengembangkan dan membatasi. Untuk itu perndidikan tinggi bertugas untuk mendekatkan jarak keduanya melalui kajian-kajina ilmiah baik ilmu agama mauipun ilmu keislaman. Dikotomi antara islam dan ilmu 
pengetahuan (science) dalam kajian keilmuan sudah harus diakhiri. Di sinilah pentingnya merubah pendekatan (metodologi) dan reorientasi kajian islam dan ilmu pengetahuan (science) (Ishomuddin, 2011:154). Pendidikan Tinggi Pesantren sebagai Pusat Pengembangan Islam ke depan secara umum harus mentransformasi nilai-nilai pesantren dalam sains, teknologi, seni, masyarakat, lingkungan, berupa: (1) unifikasi; (2) konkretisasi, dan (3) obyektivikasi, sehingga pesantern sebagai media dakwah islam mampu tampil secara kreatif dalam mendialogkan kebudayaan lokal dan budaya baru dalam jalur islam.

Syahrizal Abbas menyampaikan bahwa kenyataan ini dapat dilihat dari lulusan perguruan tinggi di Indonesia yang: (1) belum banyak memenuhi standar akademik yang baik, sebagai layaknya lulusan perguruan tinggi pada umumnya, (2) Lulusan perguruan tinggi sangat terbatas penguasaan bidang ilmu yang ditekunimya, (3) profesionalisme yang rendah, dan kesadaran riset yang terbatas, telah menyebabkan mereka tidak aplicabel dan marketable (Abbas, 2008:2). Menghadapi kondisi semacam itu maka perguruan tinggi agama islam dituntut mampu merespon secara akademik yakni melahirkan sarjana yang menguasai dan mampu mengembangkan ilmu pengetahuan modern berbasis pada teknologi komunikasi dan sekaligus bertakwa kepada Allah.

Persoalan lai yang menjadi tantangan pengembangan pendidikan tinggi di pesantren adalah dominasi dharma pendidikan dan pengajaran, mengecilnya riset dan pengabdian masyarakat telah menyebabkan lulusan perguruan tinggi hanya melakukan transfer pengetahuan (transfer of knowledge), sehingga kesadaran riset dan pengabdian kepada masyarakat semakin rendah. Ada tiga hal yang harus menjadi fokus penguatan pendidikan tinggi di pesantren. Pertama, tamaddun (profesionalisasi manajemen dan administrasi). Kedua, tsaqofah (kemampuan memberikan pencerahan kepada umat agar kreatif- 
produktif dengan tidak melupakan orosinalitas ajaran islam). Ketiga, hadharah (membangun budaya bangsa yang diwarnai oleh jiwa dan tradisi islam, mengembangkan dan mempengaruhi tradisi yang bersemangat islam di tengah deru dahsyat globalisasi dan terus berikhtiar menyeragamkan budaya melalui produk-produk teknologi.

4. Pendidikan Tinggi Pesantren dan Pusat Pengembangan Keilmuan, Dakwah

Islam dengan paradigma yang dimilikinya yaitu rahmatan lil alamin yang sejatinya sebagai elemen dasar yang ditanamkan kedalam jiwa para santrinya dapat mengatasi benturan-benturan peradaban atau implikasi negatif dari perkembangan dunia karena pesantren adalah bagian integral dari masyarakat secara keseluruhan yang tidak mungkin menutup mata dan menjauh dari realitas yang ada. Keterpaduan syariat Islam, sains, teknologi, dan seni dengan nilai-nilai pesantren dapat diaktualisasikan dengan upaya serius di lingkungan pendidikan tinggi pesantren. Pesantren sebagai sebuah lembaga yang paling memungkinkan ke arah pembentukan masyarakat madani sangat diharapkan mampu mengantarkan peserta didiknya sebagai subyek atau pelaku utama yang akan mampu bergerak terpadu memadukan sains, teknologi, seni, nilai, dan lingkungan dalam proses membangun individuindividu masyarakat

Menurut Brodjonegoro yang disampaikan E.A. Kuncoro bahwa untuk meningkatkan daya saing dan mutu perguruan tinggi, maka perlu diupayakan adanya indicator kinerja perguruan tinggi, yang untuk sementara dapat dinyatakan dalam: (1) kuantitas dan kualitas serta relevansi lulusan, (2) kuantitas dan kualitas serta relevansi hasil penelitian dan pengembangan, (3) kuantitas dan kualitas dan relevansi kegiatan pengabdian pada masyarakat (Koncoro, 2009:120).

Pendidikan tinggi di pesantren diharapakan dapat berperan secara optimal dan global, sebab sebagai bagian dari satuan pendidikan 
dituntut untuk senantiasa merevitalisasi strateginya guna menjamin kesesuain tututan lingkungan dan persaingan dengan kekuatan internal yang dimilikinya. Ini penting mengingat ketidakmampuan suatu satuan pendidikan dalam merespons peluang dan ancaman eksternal akan mengakibatkan menurunnya daya saing dan atau terhambatnya pencapaian kinerja satuan pendidikan itu. Jika hal ini dibiarkan maka akan mengancam kelangsungan satuan pendidikan yang bersangkutan (Rahayu, 2009:64).

Dalam dekade teakhir ini, pendidikan tinggi di Indonesia mengalami perubahan paradigma yang cukup signifikan. Perubahan paradigma yang dimaksud adalah meliputi perubahan paradigma pengelolaan persaingan. Perubahan ini terpicu oleh perkembangan lingkungan eksternal yang sangat dinamis menyangkut perkembangan teknologi informasi, sehinga e-learning, euniversity dan sejenisnya mulai banyak dibicarakan dan diusahakan Menurut Gaffar (Soegoto, 2008:61) menjelaskan bahwa perguruan tinggi dengan misi yang diembannya, yakni pendidikan dan pengajaran, penelitian dan pengembangan, serta pengabdian kepada masyarakat, seyogianya memberikan kontribusi yang fungsional dalam menjawab permasalahan yang dihadapi masyarakat. Sejalan dengan itu, pengembangan ilmu pengetahuan dan teknologi dilingkungan perguruan tinggi dilakukan melalui kegiatan tridharma sesuai dengan kebutuhan pembangunan sekarang dan masa depan.

Kehidupan kampus harus dikembangkan sebagai lingkungan masyarakt ilmiah yang dinamis, berwawasan budaya bangsa yang plural, bermoral dan berkepribadian Indonesia. Kiprah perguruan tinggi juga harus dipusatkan pada optimalisasi kontribusi terhadap upaya peningkatan kualitas hidup dan kehidpuan bangsa Indonesia, pengembangan ilmu pengetahuan dan teknologi, kehidupan kebudayaan dan identitas kebangsaan. Dengan demikian perguruan tinggi akan 
tampil sebagai pemuka dalam pengembangan peradaban bangsa, yang pada gilirannya menjadi andalan seluruh bangsa ini. Kiprah ini meletakkan perguruan tinggi sebagai titik strategis pembangunan nasional dan sebagai asset nasional yang harus terus tumbuh dan berkembang (Koncoro, 2009:100).

\section{KESIMPULAN}

1. Pesantren yang mengembangkan pendidikan tinggi harus mampu mentransformasi diri dengan perkembangan globalisasi dan millinium ketiga yang ditandai dengan informasi serta perkembangan ilmu pengetahuan yang cepat.

2. Pada pengembangan pendidikan tinggi, Pesanttren menjadi lembaga pendidikan yang memiliki ciri khas dan kekhususan pada sisi kultural, namun memiliki kekuatan secara menejerial, filosifis bahkan metodologis.

3. Sumberdaya yang dihasilkan oleh pesantren memiliki multitalenta sebagai jawaban terhadap kebutuhan masyarakat global dengan karakteristik SDM yang religious dan saintis. Pribadi yang kuat, multitalenta seta memiliki skill yang bervariasi adalah ciri dari produk pesantren yang mengembangkan pendidikan tinggi.

\section{DAFTAR RUJUKAN}

A.Kadir, H. Muslim. Ilmu Islam Terapan. Yogyakarta: Pustaka Pelajar. 2003

Abbas, Syahrizal. Managemen Perguruan Tinggi. Jakarta: Kencana Prenada Media Group. 2009

Abdullah, Amin, dkk. Islamic Studies dalam Paradigma Integrasi-Interkoneksi. Yogyakarta: Penerbit SUKA Press.2007

Abdulhameed, Sultan. Al-Qur'an Untuk Hidupmu. Jakarta: Outskirts Press. 2012 
al Idrus, S. (2016). MENAKAR PERAN PESANTREN DALAM MENGEMBANGKAN PENDIDIKAN TINGGI MENGHADAPI ERA GLOBALISASI. JURNAL TATSQIF, 14(2). Retrieved from http://ejurnal.iainmataram.ac.id/index.php/tatsqif/article/view/1082

Abdul Wahab, Solichin. Pengantar Analisis Kebijakan Publik. Malang: UMM Press. 2011

Arif, Mahmud. Pendidikan Islam Transformatif. Yogyakarta: LKIS. 2008

Azra, Azyumardi. Pendidikan Islam Tradisi dan Modernisasi di Tengah Tantangan Milenium III. Jakarta: Kencana Prenada Media Group. 2012

Barizi, Ahmad. Pendidikan Integratif. Malang: UIN-Maliki Press. 2011

Barizi, Ahmad dan Mujtahid. Membangun Pendidikan dalam Bingkai Lintas Batas. Malang: UIN-Maliki Press. 2011

Best, John.W. Metodologi Penelitian Pendidikan. Surabaya: Usaha Nasional. 1982

Chan, Sam N. dan Sam, Tuti T. Analisis SWOT Kebijakan Pendidikan Era Otonomi Daerah. Jakarta: RajaGrafindo Persada. 2005

Edward Sallis, Total Quality Management in Education. Yogyakarta: IRCiSoD. 2010

Fattah, Nanang. Landasan Manajemen Pendidikan. Bandung: Remaja Rosdakarya. 2008

Ghafur, Hanif Saha. Manajemen Penjaminan Mutu Perguruan Tinggi di Indonesia. Jakarta: Bumi Aksara. 2008

Hasan, Mohd Kamal. Reclaiming The Conversation Islamic Intellectual Tradition in The Malay Archipelago. Kuala Lumpur: The Other Press. 2010

Hamidi. Metode Penelitian Kualitatif. Malang: UMM Press. 2010

Hikmat. Manajemen Pendidikan. Bandung: Pustaka Setia. 2009

Hunger. J.David dan Wheelen, Thomas L. Manajemen Strategis. Yogyakarta: Penerbit ANDI. 2003

Indrajit, Eko dan Djokopranoto. Managemen Perguruan Tinggi Modern. Yogyakarta: CV.ANDI OFFEST (Penerbit ANDI). 2006

Ishomuddin. 2011. Restorasi PTAIN di Era Globalisasi: Dinamika UIN Malang di Tangan Pemimpin Inovatif dan Kreatif. Dalam buku Membangun 
al Idrus, S. (2016). MENAKAR PERAN PESANTREN DALAM MENGEMBANGKAN PENDIDIKAN TINGGI MENGHADAPI ERA GLOBALISASI. JURNAL TATSQIF, 14(2). Retrieved from http://ejurnal.iainmataram.ac.id/index.php/tatsqif/article/view/1082

Pendidikan dalam bingkai Islam Lintas Batas. UIN Pers. Malang. (149-153)

Kodrat, David Sukardi. Manajemen Strategi. Yogyakarta: Graha Ilmu. 2009

Koncoro, E. A. Leadership Sebagai Primary Forces Dalam Competitive Strength, Competitive Area, Competitive Result Guna Meningkatkan Daya Saing Perguruan Tinggi dalam buku Manajemen Corporate \& Strategi Pemasaran Jasa Pendidikan. PT. Alfabeta Bandung: 2009:100.

Langgulung, Hasan. Pendidikan Islam dalam Abad ke-21. Jakarta: Pustaka Alhusna Baru. 2003

Littlejohn, Stephen W dan foss. Karen A. Teori Komunikasi. Jakarta: Salemba Humanika. 2009

Mastuhu. Memeberdayakan Sistem Pendidikan Islam. Jakarta: Logos Wacana Ilmu. 1999.

Maunah, Binti. Tradisi Intelektual Santri dalam Tantangan dan Hambatan Pendidikan Pesantren Masa Depan. Yogyakarta: Penerbit TERAS. 2009

Muchsin, H.M.Bashori, dkk. Pendidikan Islam Humanistik. Bandung: Refika Aditama. 2010

Muhaimin. Pemikiran dan Aktualisasi Pengembangan Pendidikan Islam. Jakarta: RajaGrafindo Persada. 2011

Mujib, Abdul dan Mudzakkir, Jusuf. Ilmu Pendidikan Islam. Jakarta: Kencana Prenada Media Group. 2006

Muliawan, Jasa Ungguh. Pendidikan Islam Integratif. Yogyakarta: Pustaka Pelajar. 2005

Mulyono. Manajemen Organisasi dan Organisasi Pendidikan. Yogyakarta: ArRuzz Media. 2008

Mulyasa, E. Manajemen Berbasis Sekolah. Bandung: Remaja Rosdakarya. 2007 Muqodim. Manajemen Perubahan di Perguruan Tinggi Islam. Yogyakarta: EKONISIA. 2006 
al Idrus, S. (2016). MENAKAR PERAN PESANTREN DALAM MENGEMBANGKAN PENDIDIKAN TINGGI

MENGHADAPI ERA GLOBALISASI. JURNAL TATSQIF, 14(2). Retrieved from http://ejurnal.iainmataram.ac.id/index.php/tatsqif/article/view/1082

Nata, Abuddin. Metodologi Studi Islam. Jakarta: RadjaGrafindo Persada. 2000

Nata, Abuddin. Manajemen Pendidikan. Jakarta: Kencana Prenada Media Group. 2008

Nawawi, H.Hadari. Manajemen Strategik. Yogyakarta: Gadjah Mada University Press. 2005

Nawawi, H.Hadari dan Martini, H. Mimi. Kebijakan Pendidikan di Indonesia Ditinjaun dari Sudut Hukum. Yogyakarta: Gadjah Mada University Press. 1994

Notodihardjo, Hardjono. Pendidikan Tinggi dan Tenaga Tingkat Tinggi di Indonesia. Jakarta: UI Press. 1990

P. Siagan, Sondang. Managemen Strategik. Jakarta: Bumi Aksara.2008

Patilima Hamid. Metode Penelitian Kualitatif. Bandung: ALFABETA. 2011

Pearce, John A. dan Robinson, Richard B. Manajemen Strategik. Jakarta: Binarupa Aksara Publisher.

Pidarta, Made. Perencanaan Pendidikan Partisipatori dengan Pendekatan Sistem. Jakarta: Rineka Cipta. 1990

Prabowo, Sugeng Listyo. Implementasi Sistem Manajemen Mutu. Malang: UINMaliki Press. 2009

Riduwan. Metode dan Teknik Menyusun Proposal Penelitian. Bandung: ALFABETA. 2010

Rivai, Veitzal dan Murni Sylviana. Education Management. Jakarta: Raja Grafindo Persada. 2009

Robinson, Pearce. Manajemen Strategik. Jakarta: Binarupa Aksara. 1997

Rukmana, Nana. Strategic Parterning for Education Management. Bandung: ALFABETA. 2006

Sagala, Syaiful. Managemen Strategik dalam Peningkatan Mutu Pendidikan. Bandung: ALFABETA. 2011

Saud, Udin Saefudin. Inovasi Pendidikan. Bandung: ALFABETA. 2008

Saud, Udin Saefudin dan Makmun, Abin Syamsuddin. Perencanaan Pendidikan. Bandung: Rosdakarya. 2011 
al Idrus, S. (2016). MENAKAR PERAN PESANTREN DALAM MENGEMBANGKAN PENDIDIKAN TINGGI MENGHADAPI ERA GLOBALISASI. JURNAL TATSQIF, 14(2). Retrieved from http://ejurnal.iainmataram.ac.id/index.php/tatsqif/article/view/1082

Sihab, Quraish. Bisnis Sukses Dunia Akhirat. Jakarta: Lentera Hati.

Subhan, Arif. Lembaga Pendidikan Islam Indonesia Abad ke-20. Jakarta: Kencana Prenada Media Group. 2012

Sudjana, Nana dan Ibrahim. Penelitian dan Penilaian Pendidikan. Bandung: Sinar Baru Algensindo. 2009

Sugiyono. Memahami Penelitian Kualitatif. Bandung: ALFABETA. 2013

Sugiyono. Metode Penelitian Kuantitatif kualkitatif dan R\&D. Bandung: ALFABETA. 2009

Suprayogo, Imam dan Rasmianto. Perubahan Pendidikan Tinggi Islam. Malang: UIN-Maliki Press. 2008

Suprayogo, Imam. Universitas Islam Unggul. UIN-Maliki Press. 2009

Sutrisno. Pendidikan Islam yang Menghidupkan. Yogyakarta: Kota Kembang. 2008

Suprayogo, Imam. Kepemimpinan. UIN-Maliki Press. 2010

Suwignyo, Agus. Pendidikan Tinggi dan Goncangan Perubahan. Yogyakarta:P Pustaka Pelajar. 2008

Tilaar. Paradigma Baru Pendidikan Nasional. Jakarta: Rineka Cipta. 2000

Tilaar, H.A.R. Manajemen Pendidikan Nasional. Bandung: Remaja Rosdakarya. 2001

Tolkhah, Imam dan Barizi, Ahmad. Membuka Jendela Pendidikan. Jakarta: RajaGrafindo Persada. 2004

Yukl, Gary. Kepemimpinan dalam Organisasi. Jakarta: Bhuana Ilmu Populer. 1994

Qomar, Mujamil. Manajemen Pendidikan Islam. Yogyakarta: Penerbit Erlangga. 2007

Zubaedi. Islam dan Benturan Antar Peradaban. Yogyakarta: Ar-Ruzz Media. 2007 